\title{
European Monetary Measures to Support Economic Recovery
}

\author{
PhD, Bogdan Munteanu
}

Associated lecturer, Department of International Relations and European Integration

National School of Political and Administrative Studies, Bucharest

\begin{abstract}
The present article aims to look at the current monetary measures deployed by ECB to address the economic context of below expectations economic growth and inflation, taking into account the expression of monetary policy via the Expanded Asset Purchase Programme. This tool is used to push financial liquidity into the economies of the European Union, in a banking system affected by the crisis and which has been shown to be still at risk by the latest stress tests conducted by the European Banking Authority. The article points out why monetary measures are important to support the economic recovery in Europe, in an interventional context of monetary and fiscal policies of governing authorities, appealing to economic models to explain how the policies contribute to economic growth and development. The methodology used by the article is economic analysis and rationale, cost-benefit analysis, statistics of money market and banking industry indicators, etc. The conclusion emerging from this article is that the Asset Purchase Programme of ECB led in a certain degree to an improvement in the macro-economic environment on yields and on its transmission channels into the financial system and into economies.
\end{abstract}

Keywords: Debt, Expanded Asset Purchase Programme, Inflation, Interest Rate, Monetary Measures, Quantitative Easing. JEL Codes: E44, E51, E52, E58, G12

\section{Introduction}

In the present state of the European economies facing unemployment and slow GDP growth, in an environment of close to zero or negative interest rates (e. g. EURIBOR ${ }^{1}$ or EUR key reference rate ${ }^{2}$ ), the preference for liquidity is high. This liquidity should translate into investments that generate positive returns that lead to a raise in GDP (economic growth) and translates into wages increase and job creation as part of economic development (economic development seen in the welfare of a society).

The main mission of European Central Bank (ECB) is to control inflation by maintaining the stability of prices ${ }^{3}$ via a wide range of monetary measures. The prices are the transfer mechanism of money in exchange for property or ownership of goods and services. When prices are stable, they favour equitable redistribution of wealth. A deflation in EU is impacting distribution of monetary resources. Negative interest rates erode capital and sever the incentive for saving.

ECB implemented the monetary measure called "Expanded Asset Purchase Programme"4 as a Quantitative Easing mechanism to increase the monetary mass to release liquidity to national banks and in the end to commercial and retail banks, in order to finance business. The monetary mass should be relative to favouring inflation around $2 \%$. Today, the threat is called deflation (falling prices leading to decreasing inflation below $2 \%$ and into negative territory). Deflation means that merchandise is cheaper and the turnovers of companies decrease (quantity sold multiplied by falling prices).

\footnotetext{
1 http://www.euribor-rates.eu/

$2 \mathrm{https://www.ecb.europa.eu/stats/monetary/rates/html/index.en.html}$

${ }^{3}$ ECB: Our role - "Our main aim is to maintain price stability, i.e. to safeguard the value of the euro. Price stability is essential for economic growth and job creation - two of the European Union's objectives - and it represents the most important contribution monetary policy can make in that area." (http://www.ecb.europa.eu/ecb/tasks/html/index.en.html)

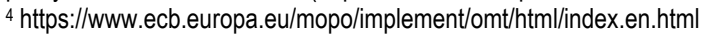


Companies will produce less and will adjust costs and people will cut consumption and push further the pressure on companies.

It is a related spiral between the phases of economic cycles, the abundance or scarcity of money and the reflection in price of money (interest rate) with a direct consequence on returns (yields) and job creation or contraction in an open economy. When money (priced at low interest rates) floods the economy, a part is transferred into investments (job creation) and a part in consumption (that gets back to companies via the turnovers, into profits and expansion). When investments turn unprofitable (errors in value assessment or in appraisal of fair market value) in an economy, the loss is always expressed in financial denomination. Consequently, scarcity of money affects jobs, consumption and turnovers decrease, leading to the contraction of economic activities. That is why, in the present economic context, EU needs to deploy the set of instruments to direct the financial flows of money, due to the following reasons: an imperfect monetary union; no fiscal union and governments failed to keep fiscal deficit below $3 \%$, the structural fiscal deficit below $0.5 \%$ or for some industries $1 \%$ and public debt below $60 \%$ (in EA19, the public debt is above $90 \%$ - see Eurostat, June 2016 ) 1 .

To support the economic recovery, in Keynesian philosophy, in economic downturn any central bank should print money and distribute cheaply in the economy to boost consumption (demand side measures) and to trigger an increase in employment (supply side measures), since unemployment is a structural problem of the economy, that can only be addressed on long run² (Jahan, Mahmud and Papageorgiou, 2014).

In this article I appeal to J. M. Keynes' macroeconomic theory ${ }^{3}$ (expressed in various macro-economic models) to explain why the European Central Bank ${ }^{4}$ targets access to money "at any cost" to boost economic development by monetary measures. In Hicks-Hansen model of an open economy, there is a direct relation between "Investments" and "Savings" (IS) and "Labour" and "Money" (LM) as liquidity preference under free trade and resource optimization reflected in the Balance of Payments (BoP) which stands for the allocation of flows of money. Because IS-LM model took into account only a closed economy (autarky), Mundell - Flemming model explains why in an open economy the monetary policies are not independent but correlated. Managing economic development by fiscal policy (taxes) and monetary policy (interest rate and foreign exchange rate), one cannot have fixed exchange rates, free capital movement (transfer of efficiency by price of money - interest rate and taxation) and uncorrelated decision for monetary policies (the case of EU28, EA19 where currencies fluctuate in range to EUR, interest rates follow EUR reference rate and fiscal policies are independent but guided by 2 significant benchmarks - public debt and fiscal deficit).

Investments and savings are a part of income, translated into money as mean of economic growth. The intersection of IS and LM graphic lines shows the equilibrium and what policies should be approached to boost Real Gross Domestic Product. Liquidity under this model and the quantity of money should be seen taking in account the preference for liquidity under economic uncertainties. By increasing government spending (when financial markets are imperfectly functional) a country can spend more than what it can produce (Keynes, 1936). This can be achieved by assuming a budget deficit (short term debt) or by taking loans from private and public lenders on long term (public debt) ${ }^{5}$. The fiscal and monetary policies are complementary one to the other. When the government spends, the national bank should control the quantity of money and inflation. When interest rates are low and inflation is controlled (cheap price of investments), the fiscal authorities should adopt an anti-cyclical approach: collect taxes and make reserves for future spending (control of public debt and fiscal deficit).

\footnotetext{
1 http://ec.europa.eu/eurostat/statistics-explained/index.php/Government_finance_statistics_-_quarterly_data

$2 \mathrm{http}: / /$ www.imf.org/external/pubs/ft/fandd/2014/09/basics.htm

3 John Maynard Keynes, "The General Theory of Employment, Interest and Money", 1936

${ }^{4}$ ECB launched in 2012 the Outright Monetary Tranzactions (http://www.ecb.europa.eu/press/pr/date/2012/html/pr120906_1.en.html). Mario Draghi, president of ECB, gave "whatever it takes" speech in 2012

(https://www.ecb.europa.eu/press/key/date/2012/html/sp120726.en.html) and announced in June 2014 the start of Asset Purchase Programme (https://www.ecb.europa.eu/press/key/date/2014/html/sp140911_1.en.html) and in 2015 expanded it (https://www.ecb.europa.eu/press/pr/date/2015/html/pr150122_1.en.html).

5 J.M. Keynes: "On the other hand, a decline in income due to a decline in the level of employment, if it goes far, may even cause consumption to exceed income not only by some individuals and institutions using up the financial reserves which they have accumulated in better times, but also by the government, which will be liable, willingly or unwillingly, to run into a budgetary deficit or will provide unemployment relief" page 53
} 
Across EU, there is a need for better managing the consequences of 2008 crisis. The European System of Central Banks (ESCB) implemented strategies to sustain financial actions, so that financial investments should create new jobs, being the easy way for central banks to distribute new money to markets, at low interest rates, raising inflation and consumption.

In a study paper ${ }^{1}$ (ECB, August 2016), it is found that the negatively correlated "production" and "unemployment" duo can be a reliable indicator of the trend phase in which the economy is and macroeconomic data is showing the efficiency of monetary measures taken. The unusual money market measures represent a financial disruption of normal financial conditions, influencing directly the labour market (demand side impact), pushing upwards the capital markets (supply side impact).

Today, due to "expanded asset purchase programme" mechanism in place from ECB, liquidity is flooding the money markets, in Euro Area directly and all across EU indirectly. The effect is that this excess of liquidity, instead of translating into investments, mainly stayed in the money market system as cash, driving the price of money, i. e. interest rates to zero levels or below zero levels ( "money for free"?), leading to deflation or low levels of inflation ( "crawling inflation"). When prices of goods go down and money lose value, the turnover of companies decrease and, in spite of low cost of investments, profits decline or turn into actual loss. When this paradox persists (no satisfactory growth, despite access to liquidity), companies adjust to the "new normal" conditions (falling prices, excess liquidity, low cost of capital and new technologies) by restructuring activities, consumption is reduced and prices go down further, leading to another cycle. To break this chain, ECB aims at turning liquidity from QE mechanism into working capital loans for companies. The flow gets bottle-necked at commercial banks level that have the skills, tools and incentive to take on lending risks in their balance sheet, provided that they comply with capital requirements and non-performing loans ratios in conjunction with risk-weighted assets.

The banking system in European Union recovered partially and differently from the financial crisis and the need for restructuring is also present in the banking sector (commercial banks, the ones who should support and be the backbone of economic recovery, are also announcing recession: Deutsche Bank ${ }^{2}$, ING Bank ${ }^{3}$, Unicredit ${ }^{4}$ and Monte dei Paschi di Sienna ${ }^{5}$, etc. ). The European Banking Authority recently released the results of the stress test ${ }^{6}$ conducted in 2016, analysing 51 banks and covering $15 \mathrm{EU}$ and EEA countries holding approximately $70 \%$ of banks' assets. Even if the purpose is to provide an image of how banks would perform in dire financial conditions, not having a reference level below/above which to refer to banks as losers/winners, the outcome is that there is a number of banks, some with systemic regional influence that need to improve Core Equity Tier 1 capital (CET1 as per the regulations issued by Bank for International Settlements / Basel Committee on Banking Supervision ${ }^{7}$ in the agreements of Basel II in place today and Basel III ${ }^{8}$ currently with transitory gradual calendar of implementation and final deadline of implementation March 2019). Starting from 2015, the banks should keep a minimum ratio CET1 per Risk Weighted Assets of $4.5 \%$. In EU, this is transposed in legislation ${ }^{9}$, by Capital Requirements Regulation ${ }^{10}$ (CRR - EU Regulation 575/2013) and Capital Requirements Directive ${ }^{11}$ (CRD 4 - Directive 2013/36/EU), along with Bank Recovery and Resolution Directive (BRRD DIRECTIVE 2014/59/EU) and Deposit Guarantee Schemes Directive (DGSD - DIRECTIVE 2014/49/EU). In order to strengthen the financial environment, the Single Rulebook ${ }^{12}$ unites all 4 documents for a "resilient, transparent and efficient banking sector".

The Expanded Asset Purchase Programme set up by the European Central Bank for private and public sectors securities provides liquidity on the financial markets through the money market. However, ECB cannot simply "print" money, it needs to sell the asset called "money" and buy other assets (third covered bonds, asset-backed securities, public sector securities

\footnotetext{
1 https://www.ecb.europa.eu/pub/pdf/scpops/ecbop175.en.pdf?b0080484af75491e40010fc129b53967

$2 \mathrm{http}: / / w w w . r e u t e r s . c o m / a r t i c l e / u s-g e r m a n y-d e u t s c h e-b a n k-j o b s-i d U S K B N 12 E 16 T$

${ }^{3} \mathrm{http}: / /$ www.reuters.com/article/us-ing-groep-strategy-idUSKCN1230D3

${ }^{4} \mathrm{https}$ ://www.bloomberg.com/news/articles/2016-12-20/saving-italy-s-banks-means-missing-public-debt-target-once-again

${ }^{5} \mathrm{https}$ ://www.bloomberg.com/news/articles/2016-12-22/monte-paschi-said-headed-for-nationalization-after-sale-failure

${ }^{6} \mathrm{http}: / /$ www.eba.europa.eu/documents/10180/1532819/2016-EU-wide-stress-test-Results.pdf

${ }^{7}$ http://www.bis.org/bcbs/index.htm?m=3\%7C14

$8 \mathrm{http}: / /$ www.bis.org/bcbs/basel3.htm?m=3\%7C14\%7C572

${ }^{9} \mathrm{http} / / /$ www.eba.europa.eu/regulation-and-policy/implementing-basel-iii-europe

$10 \mathrm{http}: / /$ eur-lex.europa.eu/LexUriServ/LexUriServ.do?uri=OJ:L:2013:321:0006:0342:EN:PDF

$11 \mathrm{http}: / /$ eur-lex.europa.eu/legal-content/EN/TXT/?uri=CELEX:32013L0036

$12 \mathrm{http}: / /$ www.eba.europa.eu/regulation-and-policy/single-rulebook
} 
and private sector securities - usually bonds), as an exchange: ECB pays the price in cash for the tradable assets (debt and capital instruments, as well as derivatives). The average value of monthly purchases by ECB is around EUR 80 billion $^{1}$, targeting also the long term refinancing operations and what is actually does is to de-stress the leveraged countries (mainly buying sovereign debt, partly to give time and liquidity to make structural economic adjustments to finance investments through the financial sector and create new jobs). The effect of the programme ${ }^{2}$ is "the removal of duration risk and the relaxation of leverage constraints for financial intermediaries" (ECB, September 2016). Currently, the total purchase is EUR 1306 billion out of which, the public sector purchase represents $81 \%$ (ECB, October 2016).

Concluding, ECB's QE should be effective to combat economic downturn. Since launching in 2015, almost 2 years passing it is a too-short timeframe to tell. ECB released in September 2016 an "early assessment", looking on the monetary mechanism of transmission and how it works delivering the necessary liquidity to financial markets. What it does not cover is the second part, from financial private institutions, further to companies and the third chain, to employees. This points out that some improvement in the macroeconomic environment can be seen: the effects of the European Central Bank's expanded asset purchase programme on yields and on the macro-economy and sheds some light on its transmission channels. It shows that the programme has significantly and persistently reduced sovereign yields on long-term bonds and raised the share prices of banks that held more sovereign bonds in their portfolios (ECB, August 2016).

\section{NOTES}

The purpose of this article is to analyse public data and information. All this information is available from public sources in a complete form and according to specified methodology and can be accessed and seen in the sources indicated for reference. Therefore, it is not in the scope of the article to reproduce tables and charts, but to use the relevant data to answer to questions about causes, effects, time, impacts, costs, responsibilities, actions, benefits.

This article focuses on a very specific subject and takes into account a dual approach (financial and economic). Being a broad topic, it needs future observation, analysis and in-depth survey on all coordinates. It remains open for further development.

\section{REFERENCES}

[1] Eurostat 150/2016

[2] Eurostat $155 / 2016$

[3] Keynes, John Maynard "The General Theory of Employment, Interest and Money", 1936

[4] Jahan, Sarwat \& Mahmud, Ahmed Saber \& Papageorgiou, Chris, "What Is Keynesian Economics?" Finance \& Development, September 2014, Vol. 51, No. 3

[5] http://www. euribor-rates. eu/

[6] https://www. ecb. europa. eu/stats/monetary/rates/html/index. en. html

[7] http://www. ecb. europa. eu/ecb/tasks/html/index. en. html

[8] https://www. ecb. europa. eu/mopo/implement/omt/html/index. en. html

[9] http://ec. europa. eu/eurostat/statistics-explained/index. php/Government_finance_statistics_-_quarterly_data

[10] http://www. ecb. europa. eu/press/pr/date/2012/html/pr120906_1. en. html

[11] https://www. ecb. europa. eu/press/key/date/2012/html/sp120726. en. html

[12] https://www. ecb. europa. eu/press/key/date/2014/html/sp140911_1. en. html

[13] https://www. ecb. europa. eu/press/pr/date/2015/html/pr150122_1. en. html

\footnotetext{
1 https://www.ecb.europa.eu/mopo/implement/omt/html/index.en.html

2 https://www.ecb.europa.eu/pub/pdf/scpwps/ecbwp1956.en.pdf
} 
[14] https://www. ecb. europa. eu/pub/pdf/scpops/ecbop175. en. pdf?b0080484af75491e40010fc129b53967

[15] http://www. reuters. com/article/us-germany-deutsche-bank-jobs-idUSKBN12E16T

[16] http://www. reuters. com/article/us-ing-groep-strategy-idUSKCN1230D3

[17] https://www. bloomberg. com/news/articles/2016-12-20/saving-italy-s-banks-means-missing-public-debt-targetonce-again

[18] https://www. bloomberg. com/news/articles/2016-12-22/monte-paschi-said-headed-for-nationalization-aftersale-failure

[19] http://www. eba. europa. eu/documents/10180/1532819/2016-EU-wide-stress-test-Results. pdf

[20] http://www. bis. org/bcbs/index. htm?m=3\%7C14

[21] http://www. bis. org/bcbs/basel3. htm?m=3\%7C14\%7C572

[22] http://www. eba. europa. eu/regulation-and-policy/implementing-basel-iii-europe

[23] http://eur-lex. europa. eu/LexUriServ/LexUriServ. do?uri=OJ:L:2013:321:0006:0342:EN:PDF

[24] http://eur-lex. europa. eu/legal-content/EN/TXT/?uri=CELEX:32013L0036

[25] http://www. eba. europa. eu/regulation-and-policy/single-rulebook

[26] https://www. ecb. europa. eu/mopo/implement/omt/html/index. en. html

[27] https://www. ecb. europa. eu/pub/pdf/scpwps/ecbwp1956. en. pdf

[28] http://www. imf. org/external/pubs/ft/fandd/2014/09/basics. htm 